\title{
工匠北村傳兵衛がうけた建築家藤井厚二からの影響 THE CONSEQUENCE OF CARPENTER DEMBEI KITAMURA'S HAVING RECEIVED FROM ARCHITECT KOJI FUJII
}

\author{
有住侑子*, 藤田勝也** \\ Yuko ARISUMI and Masaya FUJITA
}

\begin{abstract}
The consequence from Koji Fujii was considered centering on the tearoom of the Nakano family residence. The main points of argument solved in this paper are as follows.

1. By construction of the tearoom of the Hiraike family residence, or the former Ogawa family residence, Dembei received influence from Fujii.

2. Dembei had adopted in the plan the lighting method and the ventilating method which Fujii recommends.

3. The influence from Fuji is seen in the Nakano family residence or the tearoom in Kyoto Botanical Garden.

4. He investigated the mere not a copy but original design, Dembei being affected from Fujii.
\end{abstract}

Keywords : Dembei Kitamura, Koji Fujii, tearoom, modernization, carpenter 北村傳兵衛，藤井厚二，茶室，近代，工匠

\section{1. はじめに}

本研究の目的は、京都の工匠北村傳兵衛（明治 27 年 $<1894>$ 昭 和 60 年 $<1985>$ 、以下「傳兵衛」と略称する）が受けた建築家藤井 厚二からの影響について、その実態を明らかにすることにある。一般 に人から人への「影響」は有形無形を問わず様々に想定し得るが、本 論では、傳兵衛が藤井との共同を通じて藤井の意匠や手法を自身の作 事に採り入れていることをもって「影響」とする。

北村家は代々両替商・油商を営み、安永から天明年間頃に四代目傳 兵衛が大工職に転向、昭和 60 年まで家業として継承された。屋号「房 屋」で、代々「傳兵衛」を襲名した。遡って北村家は元禄頃より東木 屋町通り（現木屋町通り）松原上る美濃屋町に居住し、工匠傳兵衛も ここを本拠に活動した。現在も大傳月軒として居宅は良好に遺る。

傳兵衛が関わった建物は京都に 100 棟近くもあったとされ、管見で は中村昌生氏が近代の工匠の一人として傳兵衛を取り上げているが 1)、詳細はほとんど知られていない。数寄屋の大工、町屋の大工とし て断片的に紹介されることがなかったわけではないものの、活動の実 態はなお不明な点が多いのが実情である注1)。

いっぽう藤井厚二 (明治 21 年 $<1888>\sim$ 昭和 13 年 $<1938>$ ) は、 京都大山崎に 1 万 2 千坪の土地を購入し、自身の理論を検証すべく 聴竹居をはじめ実験住宅と称する自邸を設計していて、建築環境工 学の草分け的存在とも評される、日本近代を代表する建築家の一人
であり、研究の蓄積は豊かである注2)。

さて、日本近代における大工と建築家との関係では、藤井にもお 抱え大工ともいうべき存在があったことは知られている注3)。しかし ながら独自に活躍した工匠と建築家の相互関係、影響関係について の詳細な考察は管見にみえない。傳兵衛については、藤井や西澤文 隆といった建築家と共同したこと自体は既知の事実だが、両者の関 係についての具体的な分析は、なされてはいない。

そこで本稿ではとくに、傳兵衛が藤井から受けた影響について、傳 兵衛が作事した、京都府長岡京市に所在する中野家住宅注 4)、なかで も敷地奥にたつ茶室を中心に検証したい。

まず、傳兵衛と藤井の共同の実態を確認した上で（第 2 節）、中野 家住宅の茶室にみられるデザインが藤井から影響を受けたものであ ることを明らかにする（第 3 節）。つぎに照明法や換気法にも藤井か らの影響がみられることを示し（第 4 節）、さらに、とはいえ傳兵衛 は藤井のデザインや手法を単に踏襲したのではなく、そこには傳兵衛 の独自性がみられることを、細部の詳細な分析を通して明らかにした い(第 5 節)。

\section{2. 傳兵衛と藤井の共同}

管見では、傳兵衛が藤井と共同した作事は少なくとも 3 件ある注5)。 平岡家住宅、平池家住宅茶室そして、旧小川家住宅であり、いずれ も藤井による設計、傳兵衛の施工である。このうち旧小川家住宅は
$*$ 和歌山大学施設整備課

** 関西大学 教授.工博
Recreational Facilities Division, Wakayama Univ.

Prof., Kansai University, Dr. Eng. 
昭和 9 年で、最後の共同であった注6)。平岡家住宅は昭和 2 年の竣工 であるが、平池家住宅茶室の竣工年は大正〜昭和初期という以上に判 然としない注7)。そこで便宜上、3 件を作事の年次順にまとめたのが 表1である。

傳兵衛は藤井との共同を通じて、その思想に触れ、影響を受けた ことは間違いない注8)。両者の深い関係の一端は、たとえば良好に現 存する傳兵衛旧邸の玄関の照明器具に見出せる注 9$) 。$ 藤井から譲渡さ れたとされるその照明器具は注 10)、藤井著『床の間』(昭和 13 年) 2 ) 掲載写真に近似する。また他にも、藤井設計の住宅にみられるペン ダント式照明器具に類似するものが確認されるところである注 ${ }^{11)} 。$

\section{3. 中野家住宅茶室にみる藤井厚二からの影響}

\section{3-1 中野家住宅の茶席天井について}

中野家住宅茶席で注目されるのは天井である。特徴として、一つに 臀の網代組であり、二つ目に床の間の前、䠰口・貴人口、茶道口で各々 天井高さを変えること（写真 1 )、三つ目に、各々の交叉部にあたる 位置の 2 箇所に埋め込み型の照明器具を設置することが挙げられる (写真 2)。

このような手法・意匠は、平池家住宅の茶席天井（表 1 の番号 2) に顕著であって、また傳兵衛による京都府立植物園内の茶室（昭和 45 年竣工）にも見出せる。そこでまず本節では、平池家住宅茶室を めぐって上記の特徴が藤井のデザインにもとづくものであることを 検証する。

\section{3-2 平池家住宅の茶室}

傳兵衛と藤井の共同によって営まれた当初の平池家茶室は現存し ない。現在の建物は創建当初の茶室を解体・撤去壊した後、昭和 50 年代に再建したものである。当家は藤井とは親戚関係にあって注 $122 、$ 昭和 20 年代に分家し、敷地中ほどに塀をたてて建物を東西に分割、 茶室は現在、西側の平池浩家住宅に付属してたつ。

茶室が位置するのは敷地の最北で、主屋からは渡り廊下で繋がる。 茶室平面は、主屋に近い側から六畕間と四畳半の 2 室をやり違えて 配置していて、両室間に二畳の水屋が付属する。造営の時期や経緯 の詳細は定かではない注 13$)$ 。現茶室は当家と付き合いのあった地元 の工務店が、創建当初の茶室の基礎上に忠実に再建したものという 注 14 。

\section{3-3 平池家住宅茶室を検証}

平池家住宅の茶室、四畳半の茶席天井には、藤井のデザインが確 認できる。
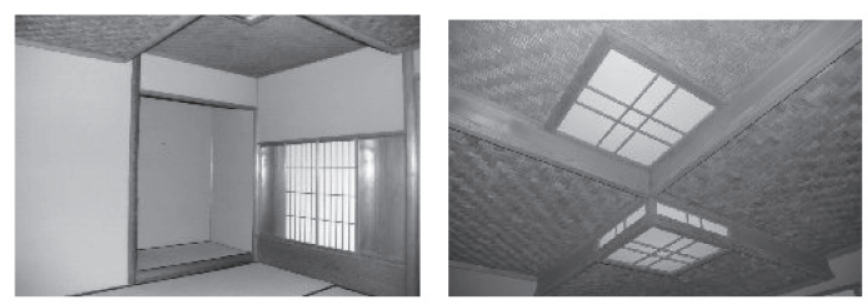

写真 1 中野家住宅の茶席内部 写真 2 中野家住宅の茶席天井

藤井の『新しき茶室建築』3) 掲載写真にこの四畳半茶席天井と近 似のデザインがみられる (写真 3 )。同書掲載の写真は寸べて藤井設 計によるもので、写真を挙げつつ自身の設計意図を説明している。こ の写真には「(前略) ・・此装置による為に天井と共に意匠せるもの」 とある。「装置」とは照明器具のこと。つまり写真の天井は藤井が天 井を照明器具と一体的に計画したものである。

上記の写真と同じ写真が前記した藤井著『床の間』にも紹介される。 藤井の住宅作品の床の間について計 38 葉の写真を紹介し、各写真下 部に簡単な説明を添える注15)。10 番目にあたるのが上記写真であって、 「十閑室の床」と題し、「設計の基礎條件が全く右の圖と同一のも のです」と記す。「右の圖」とは 9 番目の写真で、それには「此案は 閑室に於て、其の廣さが四疊半敷の場合に對する床の間です」とある。 そこで 10 番目の写真説明の「基礎條件」とは、四畳半の茶室（閑室） 注16) を指寸ことがわかる。

四冨半は平池家住宅の茶席とも合致するから、この写真は平池家住 宅の創建当初の茶席ではないかとの想定が一応可能ではある注 17)。平 池家では床の間の、向かって右手の床前に円空があって、中央に柱が 通る（写真 4)。ところが写真 3 に柱は見えない。茶室の再建で柱位 置が変更されたとも考え難いので注 18$) 、$ 写真は平池家住宅のそれでは ないらしい。

とまれ平池家住宅の茶室には、藤井のデザイン性が顕著である。こ のことを、柱の形状、埋め込み型照明器具、円空の 3 点に注目して検 証する。

まず、平池家住宅茶室における柱の形状は、2 室の茶席の柱が床柱 を除いてす心゙て面皮柱である注 19)。これは藤井設計の旧小川家住宅の 茶室とも共通する。旧小川家住宅について、面皮柱を多用する点は藤 井のほかの作品ではあまり例を見ない、との評価がある注20)。平池家 住宅茶室の面皮柱は藤井によるデザインであり、また旧小川家住宅と 共通するところから、傳兵衛との共同によるものとも推察される。

つぎに埋め込み型の照明器具について（写真 5)、藤井自身が『床 の間』や『新しき茶室建築』で紹介した藤井考案の照明器具の中に類 似のものがある（写真 $7 \cdot 8 ）$ 。埋め込み型である点はもとより、全体 のデザイン、組子の位置や本数、側面部分にも照明機能をもつ点など、 共通点は多い。これは旧小川家住宅茶室の照明器具にも通じる（写真 6)。 さらに、平池家住宅茶室の床前に円空がある。この円空は茶室北面

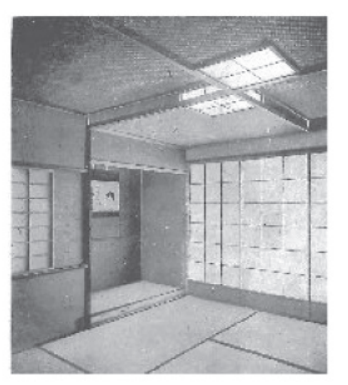

写真 3 藤井厚二設計の茶室

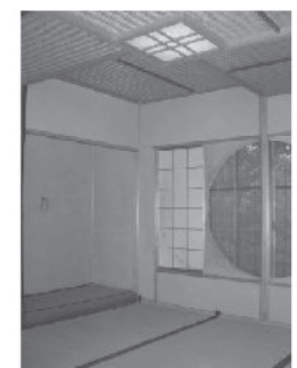

写真 4 平池家住宅の茶室

表 1 傳兵衛が藤井厚二と関わった作事一覧

\begin{tabular}{|c|c|c|c|c|c|c|}
\hline & 竣工年 & 建築名 & 所在地 & 施主 & 構造 & 現存 \\
\hline 1 & 1927 (昭和2) & 平岡家住宅 & 京都府 左京区松ヶ崎樋ノ上町 25 & 平岡尚 (7代目平岡利兵衛) & 木造2階建か & 現存せず \\
\hline 2 & 大正～昭和初期 & 平池家住宅茶室 & 大阪府 㾛屋川市平池町 $12-9$ & 平池澊治 & 木造平屋建 & 再建 \\
\hline 3 & 1934(昭和9) & 旧小川家住宅 & 京都府 左京区北白川小倉町50-10 & 京都大学 医学部教授 小川睦之輔か & 木造平屋建 & 現存する \\
\hline
\end{tabular}


に位置し、前記したように中央に柱が通り、柱両側に障子各 1 枚を装 置して開閉する (写真 9)。特徽的なこの円空は旧小川家住宅の寝室 にも見られる (写真 10)。旧小川家住宅の寝室六畳間の床の間の、向 かって左手の西面に設けられる円空である。さらにまた藤井の『床の 間』でも掲載写真全 38 葉のうちの 2 葉に、類似の円空が確認できる から（写真 $11 ・ 12 ） 、$ 座敷飾り周辺における藤井創出によるデザイン であることがわかる。なお写真 12 は旧小川家住宅のものである注21)。

以上、平池家住宅における上記 3 点は、藤井著『床の間』や『新し き茶室建築』に見られ、また旧小川家住宅でも類例が確認できる。

平池家住宅の現在の茶室は前記したとおり再建によるものだが、藤 井による当初のデザインが忠実に再現、踏襲されている注 22)。それが 中野家住宅の茶席にも継承されているのである。

ちなみに円空については、藤井からの影響がうかがえる傳兵衛の作 品がある。福井家住宅の茶室「花月楼」の南面の円空で (写真 13)、 花月楼は昭和 $13 \cdot 14$ 年に福井家住宅に増築された茶室であって、設 計は傳兵衛、施工は大分県高田町の大工、安部芳雄であった注 23$) 。$

\section{4. 中野家住宅茶室の照明方法と換気法}

本節では、藤井からの影響が、中野家住宅の照明方法や換気法に 見出せることを明らかにする。

\section{4-1 藤井厚二による手法}

藤井は著書『新しき茶室建築』において、茶室における照明と換気 に関する問題点を指摘し、照明の意匠と換気方法について、自身設計 の茶室の写真を掲載しつつ設計手法を述べている。

まず照明器具については、和紙を用い、目障りとならない紙障子を 推奨する。また自身考案の照明器具として写真 (著書では「第一図」)

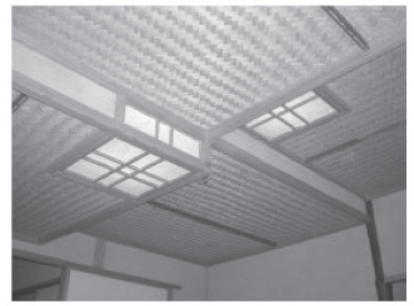

写真 5 平池家住宅の茶席天井

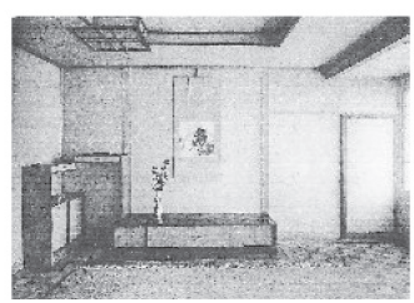

写真 7 『床の間』より

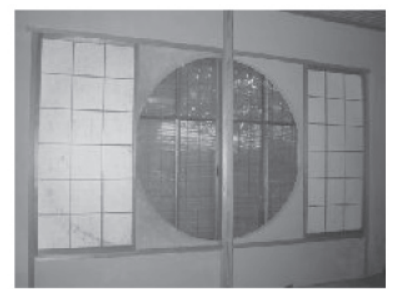

写真 9 平池家住宅茶室の円空

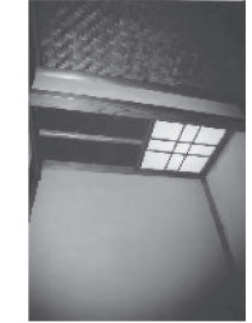

写真 6 旧小川家住宅茶室の照明器具

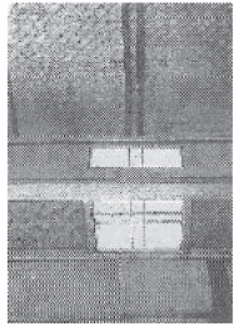

写真 8 『新しき茶室建築』より

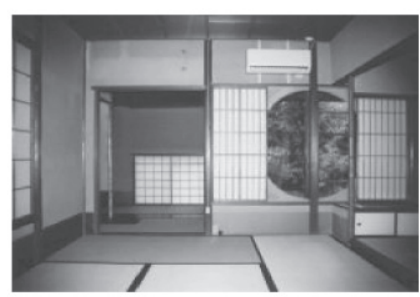

写真 10 旧小川家住寝室の円空
を示し（写真 14）、埋め込み型の照明器具とし、床と落し掛けの上部 の小壁と床天井に紙障子を嵌め込むことによって、一つの照明器具が 炉付近と床の間の両方を照らす手法を紹介している。

また換気については、入母屋造あるいは切妻造屋根の妻側壁面に換 気口を設け、屋内の污れた空気を排出する。そのために、茶室内部に も換気口を設けるが、位置は目立ためよう床の間の見返し壁面が適し ているとする注24)。

\section{4-2 中野家住宅茶室の照明器具}

茶室の照明器具は、床の間の壁上部に埋め込まれている。この照 明器具は、床の間側と外部の腰掛け側の両方の照明を兼ねる。壁に 電球を埋め込み、壁の内外両側を照らすという手法は、水屋の向か って右手、壁上部の照明器具にもみられ、水屋とともに階段下の押 入れ前付近を照らす。旧小川家住宅の茶室では、埋め込み型の照明 が床の間上部にある。床の間を照らし客座をも照らすよう、腰部分 が吹き抜けとなった床の間と境の壁の上部に装置されている（写真 6)。傳兵衛は旧小川家住宅の作事を通して藤井の手法に触れ、自身 の作品に採用したのではないかと推察される。

『中野家文書』(中野家蔵) 注 25) 所収の『中野邸數咅屋設計図』(傳 兵衛自筆）は、茶席天井の埋め込み型の照明について詳記する。「照 明八 15 角ノ紙障子トシ仕込電登卜ス」、「障子卜電球ノ間イ 45 分 明キトス」(下線は筆者) とあり、照明器具に紙を用い、障子の意匠 をデザインしていたことがわかる。これは藤井による推奨案とよく 合致するものである。

\section{4-3『中野家文書』にみられる換気法}

前記の『中野邸數部屋設計図』によれば、中野家住宅の茶席天井 に、段差を利用した開閉式の換気口を2箇所、計画していた。段差 の側面部の板材を幅 1.5 尺にわたって切り抜いた換気口であるが (写真 15)、実施施工には至っていない。史料の最下部に図があっ て、「落天 見返シ中央卜客天井見返シ中央巾 1.5 尺切抜キ廻轉トシ 換氣ヨハカル」(下線は筆者）と説明する。「見返シ」と記す設置場 所は、藤井の手法と合致する。なお藤井推奨の換気口は、旧小川家 住宅でも確認できる。北側廊下の天井に設けられ、段差を利用した 開閉式である（写真 16）。
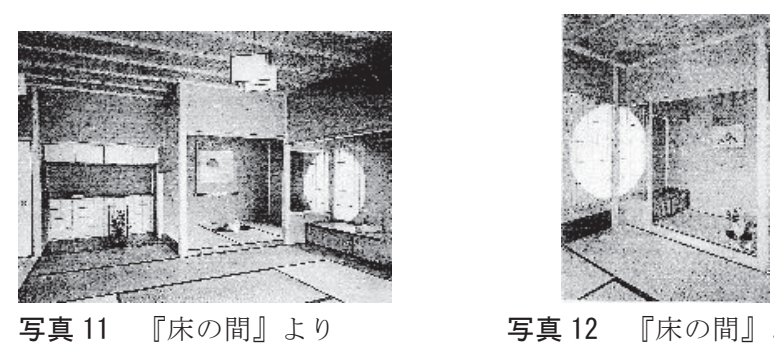

写真 11 『床の間』より

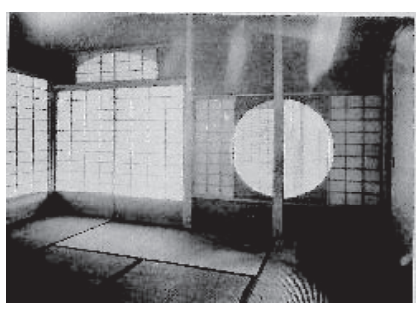

写真 13 福井家住宅茶室の円空
写真 12 『床の間』より

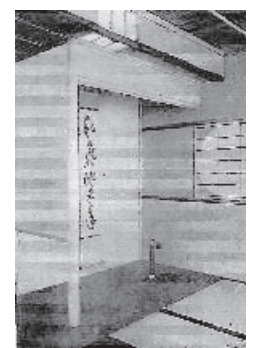

写真14『新しき茶室建築』より 


\section{5. 傳兵衛の茶席天井にみられる藤井のデザインと独自性}

中野家住宅茶室の、とくに天井に注目してみられる手法・意匠は、 平池家住宅の茶席天井に顕著であって、また傳兵衛の作事による京都 府立植物園内の茶室（昭和 45 年竣工）にも見出せることは前記した

(第 3 節)。ここでは 3 者に共通するそれら特徵について、より詳細 に検討を加えることによって、藤井から受けた影響について考察する。

\section{5-1 京都府立植物園内の茶室}

この茶室は昭和 45 年、数寄屋造りの技術の伝承・保存・展示を目 的に、京都府によって企画された。ドイッ・ミュンヘンでの茶室の 作事以降、傳兵衛は数寄屋師としてその名を知られる存在になって いたことから、この茶室も傳兵衛が担当することとなった注 27 )。茶 室は平成 $14(2002)$ 年に解体されていて現存はしないが、解体直前 の調查の際、解体時の状況が写真やヴィデオなどに記録保存されて いる注28)。

茶室は本体の建築面積 $34.7 \mathrm{~m}^{2}$ に、腰掛け待合い $9.9 \mathrm{~m}^{2} か ゙$ 付設する 構成で、北山丸太を用い、竹の組み合わせにも細かな配慮がなされ、 伝統技術が生かされている注29)。切妻造屋根で、妻面を東西に向け、 東側の貴人口上部と西の手洗い. 便所の上部に庇を掛ける。切妻造 の屋根は東側の棟が高く、西は一段下がる。屋根は上部のみを瓦莫 きとする。

内部は一畳台目の中板席と四畳半の 2 室からなる。水屋を中心に 東に四畳半の茶席、南に一畳台目の茶席を配する平面である。水屋 の南には内玄関を備え、西には手洗い・便所を設ける。茶席の四畳 半は、南に躍口、東に貴人口を矩折れに配置し、床は框床の形式で、 床前に平書院を備える。

二つの茶席のうち、中野家住宅の茶席天井に通じるデザインをも つのは、四畳半の茶席である (写真 17)。

\section{5-2 茶席天井の相互比較}

比較するのは天井の意匠と、そこに装置される照明器具の 2 点で ある。前者は、天井段差の構成、天井段差の側面部、竿縁注 30$)$ の形 状そして、天井材・意匠の計 4 点である。また後者の照明器具は、 位置と意匠の 2 点である。それら都合 6 点をめぐって、平池家、中 野家、京都府立植物園内の茶席 3 件を相互に比較・検討する。

まず、天井段差の構成について。図 1～3 は、それぞれの茶席の平

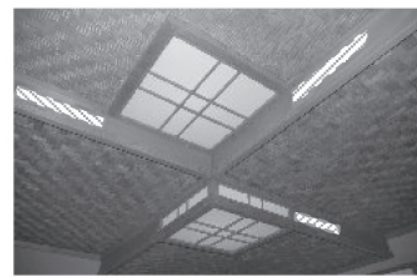

写真 15 計画された換気口注 26)

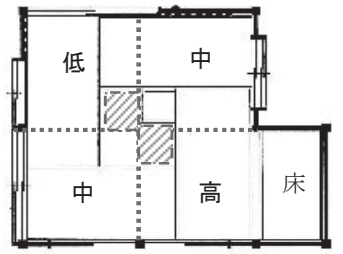

図 1 平池家住宅の茶席平面図

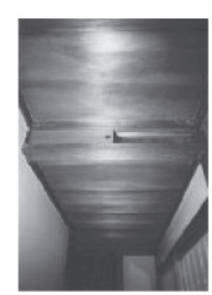

写真 16 旧小川家住宅の換気口

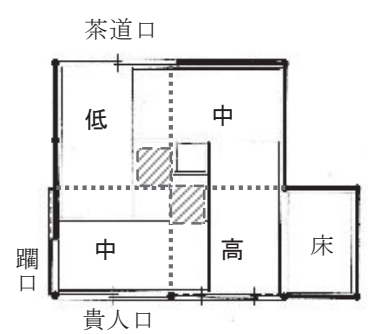

図 2 中野家住宅の茶席平面図
面図に天井段差の位置、具体的には竿縁の位置を点線で示したもの である。図は方位によらず、すべて床が右側に位置するよう描いて いる。図中の「高」「中」「低」は、天井高さの違いを示す。天井高 さの最も高い箇所が「高」、次いで高い箇所が「中」、最も低い箇所 が「低」である。

図 1〜3 をみると、3 件とも天井面を十字にちょうど 4 分割する位 置で段差を設けている。さらに天井高さの違いの配列も同じである。 すなわち床前の天井が最も高く下座を最も低くするという茶室の通 例に従いつつ、それらに接する 2 面を「中」としている。

次に、天井段差の側面部について。平池家住宅茶席と植物園内の 茶席はともに小壁である（写真 $5 \cdot 17$ )。いっぽう中野家住宅茶席の では板をはめ込む（写真 2)。前記したように中野家住宅ではここに 板を切抜いた換気口を計画していて、実施施工には至らなかったもの の、計画段階の板がそのまま用いられたものと推察される。

竿縁の形状については、平池家と中野家ではすべて角材であるが、 植物園内の茶席は角材と丸太材を併用寸る（写真 17）。

天井材・意匠について。3 件とも天井は臀を網代に組む。編み方に 注目寸ると、平池家と植物園内の茶席では、天井廻縁・竿縁に対して 斜めに編む矢羽根編だが、中野家では平行に編む石畳編としていて異 なる。

いっぽう照明器具はどうか。植物園内の茶席では天井に照明器具は 存在しないため、平池家と中野家の 2 件について比較・検討寸る。

図 1,2 に照明器具の位置を斜線で示した。両者とも天井竿縁の交点 の位置、図では左上と右下にあって一致する。

照明器具の意匠についてみると、栈の本数・位置は同一である (写 真 2 ・5)。天井高さの「低」にある照明器具は、天井の段差部分にあ たる側面の二面も同時に照らす。この手法も両者で酷似する。

以上、 3 件の茶室天井には共通点が多くみられることが判明する。 3 件の作事は古い順に、平池家茶室（大正から昭和初期）、中野家住 宅茶室（昭和 26 年）、植物園内の茶室（昭和 45 年）である。平池家 は藤井設計・傳兵衛施工、後 2 件は傳兵衛による設計・施工である。 建築家藤井厚二からの影響が中野家と植物園内の茶室にうかがえる のである。

\section{5-3 傳兵衛の独自性}

とはいえ前項の 3 件をめぐる相互比較からは、相違点もまた抽出 された。それが示唆するのは傳兵衛の独自性である。はたして傳兵 衛は、中野家住宅の作事において草案段階で推敲に推敲を重补、変更 を適宜加えつつ施工に至っていたことが、『中野家文書』によって確 認できる。以下、相違点についてさらに検証したい

まず天井段差の側面について、平池家の小壁に対して中野家では 板材をはめ込んでいた点がある。これは換気計画があったためで、
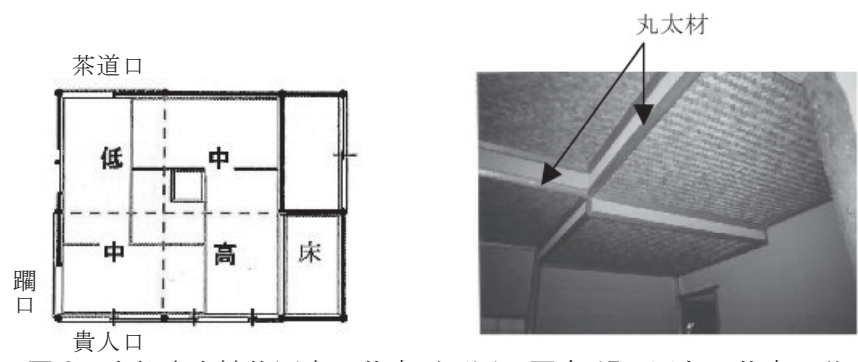

図 3 京都府立植物園内の茶席平面図 写真 17 同左の茶席天井 
前記したように、天井段差の側面部の板材を切抜いた開閉式の換気 口を傳兵衛は計画していた。このこと自体、藤井からの影響が推察 されるが (前記 4-1 参照)、この手法を積極的に自身の作事でも生か そうとしたのであった。

つぎに竿縁の形状について。平池家や中野家がすべて角材に対し、 植物園内の茶席は角材と丸太材を併用していた。京都の町屋大工は、 いわゆる数寄屋大工にみられる丸物（丸太材）を使いこなす技術を 持ち合わせていることに特徴があるという注 31 。 前記した通り、植 物園内の茶席は数寄屋技術の伝承を目的にたてられたものであった。 丸物の採用は傳兵衛の工匠としての独自性のあらわれであろう。

次に照明器具の相違について。平池家の茶席には埋め込み型の照 明器具が 2 箇所あり、前記したように照明器具と天井は一体的にデ ザインされていた。これを傳兵衛は中野家でも踏襲した。いっぽう 植物園内の茶席に照明器具はない。照明器具はないが、藤井による 天井のデザインはここでもみられる。傳兵衛は藤井のデザインを自 身のものとして消化させたのであろう。

関連して想起されるのは、傳兵衛は単なる模倣を嫌う性分であっ たということである注 32$)$ 。傳兵衛のそうした姿勢は彼の言説から窥 い知ることができる。

前記（第 2 節）したように、傳兵衛の旧邸には藤井から譲渡され たという照明器具がある。これについて「この行灯はね、藤井さん の考案になった行灯です。それをね、また私が思惑変えたんがそっ ちの。そっちのはね、風車みたいになります。その行灯は。そら、 藤井さんから一歩考えて、あんまり同じやつはいかんと思いまして ね。・・」と述懐している注 33)。あるいは、「もの真似をするのは お施主さんに対して申し訳ない。高い金を頂戴しているのだから、 他にない良いものを造らないといけない」4) とも語っている。一度 使ったデザインを二度とは使わないという。茶室建築は名席の写し が多くて面白くなく、自由にデザインできる町屋建築の方が、数段 やり甲斐があり興味があったともいわれる ${ }^{4)}$ 。

傳兵衛は決して同一のものはつくらない。作事一件ごとに工夫を 重䄈る。そうした作事にかける傳兵衛の姿勢が、藤井のデザインに 学びつつ独自の世界を生み出す原動力だったのであろう。

\section{6. おわりに}

中野家住宅の茶室を中心に、藤井厚二からの影響について検討し

た。本稿で解明した主要な論点を以下にまとめる。

(1)平池家住宅の茶室や旧小川家住宅の作事を通して、傳兵衛は藤井 から影響をうけた。

(2)藤井が推奨する照明方法や換気法を傳兵衛は計画に採り入れてい た。

(3)中野家住宅や京都府立植物園内の茶室には、藤井からの影響がみ られる。

(4)傳兵衛は藤井から影響を受けつつ、しかし単なる踏襲ではなく、 傳兵衛独自のデザインを追究した。

以上、工匠傳兵衛が受けた藤井厚二からの影響を垣間見たが、本稿 での「影響」とは、茶席の天井やその照明、換気法などごく一部に過 ぎない。しかもとくに手法や意匠に限定したものであった。対象が茶 室であるという点に、あるいはそれは起因することなのかもしれない が、しかし藤井のデザインの特質はかかる細部だけに留まるものなど
ではむろんなく、空間構成の全体におよぶ。加えて建築家としての藤 井の思想性ということもある。建築空間の全体として、さらには建築 家藤井厚二として、傳兵衛にどのように影響したのか、あるいはしな かったのか。茶室以外に考察対象を広げることが必要である。さらに 彼らの関係性を、建築あるいは建築界をとりまく当時の社会状況にい かに位置づけるのか。本稿で取り上げた傳兵衛と藤井厚二に限らず、 近代における工匠と建築家の関係について研究の蓄積は未だ少なく、 不明な点は多い。いずれも今後の課題としたい。

\section{謝辞}

建物調査に際して、中野家の現当主中野康男氏をはじめ中野家の 皆様、また平池家の現当主平池浩氏をはじめ平池家の皆様、さらに また木原千利設計工房の木原千利氏に格別のご配慮をいただいた。 傳兵衛の京都府立植物園内茶室の資料は中村昌生氏に、藤井厚二に 関する資料調査では京都工芸繊維大学の矢ヶ崎善太郎准教授に便宜 をはかっていただいた。ここに深謝する次第である。

\section{参考文献}

1）中村昌生：数寄の工匠 京都，淡交社，1986。

2) 藤井厚二 : 床の間, 藤井壽子, 1938。

3）藤井厚二 : 新しき茶室建築, 茶道全集, 第 3 巻, 創元社, 1936 に所収。

4）和風建築社編：和風建築 第 7 号，建築資料研究社， 1982 。

5）伊奈陶編：ina REPORT, No. 20，1979（後に西澤文隆 : 西澤文隆の仕事第 3 巻「つくる」, 鹿島出版会, 1988 に再録）。

6) 有住侑子・藤田勝也：中野家住宅と北村傳兵衛旧邸，日本建築学会近畿支 部研究報告集，第 51 号，pp. 897～900，2011.6。

7）財団法人 京都伝統建築技術協会編：普請 第 5 号，1980。

8）中村昌生 : 京の座敷, 駸々堂出版, 1980。

9）安井清・木原千利：蘇生する北村伝兵衛の茶室「皎庵」，住宅建築， 2009. 1 。

10）北村傳兵衛編：生空庵集，1939。

11) 建築写真類聚刊行会編輯: 建築写真類聚 7-21 数寄屋造の別荘, 洪洋社, 1933。

12）篠田銘木店 : 木，篠田銘木店，1974.12（後に伊藤ていじ監修：聞き書き 日本建築の手わざ 第 2 巻 数寄屋の職人, 平凡社, 1985 に所収。ま た一部は新建築, 新建築社, 1978.6 臨時増刊号に所収）。なお他の巻 に、傳兵衛の茶室に関する研究等が掲載されたものや、対談等を収録し たものもある（財団法人 京都伝統建築技術協会編：普請に所収）。

13）伊藤ていじ・横山正監修：現代和風建築集 第 $I$ 巻 棟梁の時代 $I$, 講 談社, 1984。

14）和風建築社：和風建築シリーズ 床の間，建築資料研究社，1998。

15）史料 京都の歴史 第 12 巻 下京区，平凡社，pp. 124 125，1981。

16）京都府教育委員会編：京都府の近代和風建築一京都府近代和風建築総合 調査報告書，2009。

17）小泉和子：建築家藤井厚二の住宅作品にみられるインテリアの特質及び 環境共生手法に関する調査研究, 京都女子大学家政学部生活造形学科, 2006 。

18）杉本菜々：藤井厚二の設計になる住宅の考察 归小川邸・八木邸の実測 調査を通じて, 日本建築学会大会学術講演梗概集（F-2 分冊）, pp. 525 $\sim 526,2006$ 。

19）石田潤一郎：関西の近代建築一ウォートルスから村野藤吾まで一，中央 公論美術出版, 1996。

注

注 1）傳兵衛とその作品に関して、参考文献 1 のほかに参考文献 4〜14 が挙 げられる。傳兵衛による作品紹介として参考文献 10 ・ 11 がある。他に 北村傳兵衛家に関する史料として『北村（伝）家文書』が京都市歴史 資料館に計 40 点所蔵される。この中に大工職関連の史料が 8 点程度含 まれるが、宝暦年間から明治初頭頃の普請願書等であって、傳兵衛以 前の史料に属する（参考文献 15）。 
注 2）藤井に関する既往研究・報告は数多いが、本稿に関連して茶室につい ては、管見では矢ケ崎善太郎「野村家の茶室について一藤井厚二の茶 室に関する研究一」『日本建築学会近畿支部研究報告集 計画系』第 44 号、1037-1040 頁、2004 年 5 月や、西澤英和「知られざる名室も うひとつの閑室をめぐって」『SD』第 432 号、2000 年 9 月、竹中工務 店設計部編『環境と共生する住宅「聴竹居」実測図集』彰国社、2001 年などがあり、ほかに参考文献 $17 \cdot 18$ 、藤岡洋保「昭和初期の近代建 築家による「床（とこ）」への関心」『日本建築学会大会学術講演梗 概集』2001 年、「藤井厚二研究一藤井家および藤井厚二を巡る人々一」 『福山大学工学部紀要』2 2 巻、2003 年、蓮井睦子ほか「住宅設計競技 にみる藤井厚二の影響一昭和初期の住宅設計にみる環境調整技術に関 する研究その 2」『日本建築学会大会学術講演梗概集』2002 年など。

注 3）藤井には、酒徳金之助という大工の存在があった。神代雄一郎「黎明 期の建築家たち 17 自邸で実験した藤井厚二」『新建築』第 38 巻、1963 年 6 月、小能林宏城「大山崎の光悦」『新建築 昭和住宅史』第 51 巻 13 号（臨時増刊）、1976 年、参考文献 18 など。

注 4）中野家住宅は平成 19 年度から実施された京都府近代和風建築総合調査 の対象に挙げられており、一次調査（関西大学建築史研究室担当）の 所見では二次調査の候補物件として推薦された。しかし二次調査の対 象とはならず、そのため近代和風建築として詳細な建物調査はなされ なかった（参考文献 16）。その後、平成 21 年の同研究室による詳細 調査の結果を踏まえ、主屋・土蔵・茶室は平成 22 年に国の登録有形文 化財に登録された。

注 5）共同はこの 3 件以外に可能性は低いのではないかと推察される。『ina Report No. 20』（参考文献 5）に傳兵衛の「主な仕事」として作事した 邸宅や別邸等を記す。大まかな所在地と、一部に設計者の氏名があり、 たとえば藤井と関係した建物については「京都市北白川 小川邸設計 者藤井厚二先生」「京阪沿線寝屋川平池邸茶室設計者藤井厚二先生」 と記す。この「藤井厚二先生」（圈点筆者）という表記は、傳兵衛自 身の紹介を示唆し、また印象に残った建物を列記したものとも考えら れ、「先生」との共同はすべて挙げているものと推測される。平岡家 住宅は、「主な仕事」欄に「京都市松ヶ崎 平岡邸設計施工」とし、 設計・施工とも傳兵衛のように記されるが、これは誤植あるいは、傳 兵衛の間違いであろう。『数寄の工匠 京都』（参考文献 1）と『和風 建築 第 7 号』（参考文献 4) は、藤井設計とする。

注 6) 『普請 第 5 号』（参考文献 7) に、傳兵衛が藤井と関わった最後の建 物であることが記される。

注 7）平池家の現当主平池浩氏によると、大正年間とも伝わる。しかし寝屋 川市編『寝屋川市史 第 7 巻』 2006 年は、昭和初期とする。

注 8) 『普請 第 5 号』（参考文献 7) に藤井の印象などが記される。

注 9）現存の照明が藤井厚二オリジナルの照明であるかどうか確証はない。

注 10）『普請 第 5 号』（参考文献 7) に、傳兵衛が「この行灯は䄈、藤井 さんの考案になった行灯です」と紹介する。

注 11）参考文献 17 参照。

注 12）藤井の妹が平池家に嫁いだ（本家の現当主平池研氏より聞き取り）。

注 13）藤井の妹が平池家に嫁いだ際に、嫁入り道具として、藤井がつくった とも伝えられる。

注 14）再建された茶室は、当初材をそのまま転用し、また実測をもとに復原 したものというわけではない。しかし一部建具の取手や、主屋と茶室 を繋ぐ渡り廊下の入口の戸板には当初材が使われている（茶室がたつ 平池家現当主平池浩氏より聞き取り）。

注 15）『床の間』初版は 1934 年であるが、1938 年に増補された。後半の 12 葉は京都帝國大學建築學教室により増補版に追加された写真であって、 説明はない

注 16）藤井は多用途に使用できる茶室を閑室と称した。閑室とは茶室の意味 も含んでいることから、ここでは茶室と同義として扱うこととする。

注 17）藤井による創建当初の茶室に関する史料は現時点では管見に確認でき ない。また写真の茶席の詳細は明らかでない。藤井厚二関係資料（京 都大学蔵）の中に、藤井設計の田中家住宅（京都市下京区染殿町、昭 和 7 年竣工）に関寸る図面・スケッチがあり、その茶室に写真のもの と類似する天井が計画されていたことがわかる。なお田中家住宅は現 存するが非公開であり、茶室の現況については不詳。

注 18）創建当初の茶室の基礎をもとに再建された（平池家の現当主平池浩氏 からの聞き取りによる）。また、円空の意匠は創建時を再現したもの と伝えられる。

注 19）角面の木皮がはがされ磨かれた柱である。いわゆる数寄屋建築に用い
られる面皮柱とは異なる。

注 20）参考文献 19 の 97 頁参照。なお参考文献 17 (239 頁) 、参考文献 18 （525 頁）はこれを継承する。

注 21）写真 11 は、藤井の遺作、扇葉荘（中田邸）の床の間である。扇葉荘 は現存しない。

注 22）再建に携わった大工にとって、茶室の作事は初めてであった。水屋の 腰板の高さについて、適当な寸法が確保されていないなど、やや不審 な点も見受けられる。平池家住宅茶室の評価を含めた詳細な調査が必 要である。

注 23）福井家と関係のあった大工か。現時点では詳細は不明。

注 24）床の間の見返し壁面とは、落し掛け上部の壁の意。

注 25）『中野家文書』(中野家蔵）の概要については参考文献 6 。

注 26）現況の写真に加筆した。3 箇所の斜線部は計画された換気口の位置を 示す。なお計画された 2 箇所は、右奥と、手前 2 箇所のどちらか一方 である。

注 27）中村昌生氏のご教示による。武内幸二という大工が傳兵衛とともに携 わっている。ドイツ・ミュンヘンの茶室は、昭和 37 年ヤンマーディ 一ゼル株式会社が同市博物館へ贈呈したもの。設計は坂倉大阪事務所 が担当し、西澤文隆が主に携わった。参考文献 4 の「私にとっての伝 兵衛さん」に詳記されるが、西澤による指名で、傳兵衛の施工が決ま った。遡って昭和 30 年、西澤は傳兵衛による塩野家茶室の改修に関 わっていて、その技術を見込んでのことであったという。

注 28）財団法人京都伝統建築技術協会による調査。

注 29）中村昌生『「数寄屋と五十年」 茶の建築の研究と和の創造をたどる』 (『茶道雑誌』初出) 、淡交社 2007 年。

注 30）「竿縁」は、『中野家文書』内の史料『中野邸數妾屋設計図』の記載 による。この竿縁は天井段差部の壁留の役割をもつたものも含まれ、 一般に通行している竿縁天井の「竿縁」とは異なる。

注 31）参考文献 1 を参照。

注 32）参考文献 1 を参照。

注 33）参考文献 7 を参照。

(2012年 3 月 10 日原稿受理，2012年 7 月11日採用決定） 